\title{
A STUDY OF BONE CONDUCTION HEARING DURING THE PERIODICAL CHANGES OF MEATAL PRESSURE IN REFERENCE TO CLINICAL PRACTICE (A NEW INTERPRETATION OF GELLE'S TEST)
}

\section{By}

\author{
R. NAKASHIMA, M.D.
}

\section{From the Department of Oto-Rhino-Laryngology, Osaka University Medical School (Director: Prof. T. Hasegawa)}

The well-known Géllés test for the diagnosis of otosclerosis has been interpreted from a new point of view, and developed the new test method that is more sensitive and simple than previous one.

The apparatus consists of audiometer, manometer and Politzer's balloon.

The procedure of the test is as follows:

The bone conduction sound of $250 \sim 4000 \mathrm{cps}$, $40 \mathrm{db}$ above threshold is imparted to the ear to. be tested, then the pressure of external auditory canal is changed periodically by pressing Politzer's balloon twice a second. The pressure is gradually enhanced and the pressure when the bone conducting tone starts to pulsate is measured by the manometer.

The results obtained with various deafness were as follows:

1) The pressure was below $5 \mathrm{mmHg}$ with those of normal hearing and perceptive deafness.

2) The pressure was above $60 \mathrm{mmHg}$ in otosclerosis.

3) In the case of other conductive deafness the pressure was $10 \sim 60 \mathrm{mmHg}$ regardless to the presence of drum perforation.

The pulsation of the bone conducting tone in this method has been proved by the experimentson the living human ear to be due to the distortion of the inner ear.

This new method which mechanism is fundamentally different from the usual modified Gélle's test, has been designated by the author as “dynamic Géllés test". The original Géllés test must be a kind of this dynamic method.

\section{外耳道動的加圧による骨導聴力の変動に関する \\ 研究並びにその臨床的応用 \\ (Géllé 検查法の新解釈)

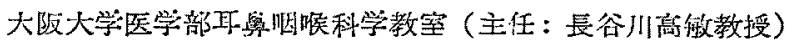

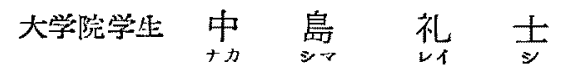

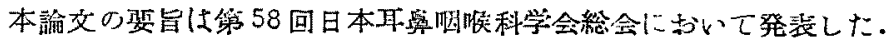

\begin{tabular}{|c|c|c|}
\hline 目 & 次 & 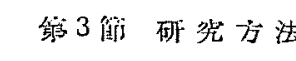 \\
\hline 第 1 算 緒 & & 研究成緒 \\
\hline 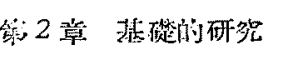 & & 第 5 俑 小 括 \\
\hline 智1節 研告対象 & & 第3章 隍林的砳究 \\
\hline 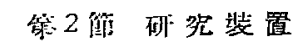 & & 第 1 舀 梌㚗 \\
\hline
\end{tabular}




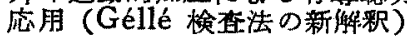

第2 笛 検查裝置

第3 節 検直力法

第 4 算 梌查成綪

管 5 節 小 括

第4 章 Géllé 現像の成立榙転について

第1 節 加圧方法について

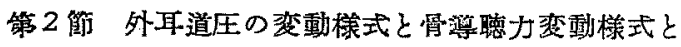
の関係

第 3 節 圐器の歪について

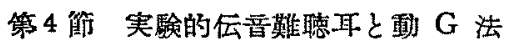

第 5 解 小 括

\section{第 5 章 栲按}

第6 章 榡語

\section{第1章 緒言}

外耳道に耳栓をしたり，鼓膜面上に 錘を乗せたりし て，伝音系江負荷を加えた場合骨導聴力が变化すること は古くから知られていた。既に1827 年Wheatstone は 「压を加えることなく外取道入口部を指で塞ぐと自分の 声が大きく聞光，音攴を頭部伅あてく外耳道を閉鎖する と音が大さくなる」と述へている，Lucae (1863) も 同様の現象を㓋察し，ある種の中耳性難恥では外耳道開 塞によつてる 骨導聴力が変化せぬことをで明らかにし た.この負荷骨尊の变化を検查して難聴の鑑別診断に 応用する方法怯その後数多く研究された. 即ち Géllé (1881) 1), Bing (1899) 2), Runge (1923) ${ }^{3)}$, Campbell \& Macfarlan (1948) 4), 恩地 (1951-55) 5), 6), 7), 8), Thullen (1952) 9), 角田 $(1954,56)^{10)}$, 11), 梦下 (1957) 12)等の検査法恃すべてこの負荷による骨導聴力の変化 を測定する方法である。この中耳硬化症の勝れた榇断法 として古くから用いられている Géllé 検查法一即ち外 耳道加圷等の聴力検查怯，その後 Griessman (1921)， van Dishoeck (1938) 14), 15), Rasmussen (1946) 16), 17), Thullen (1954) 9), 松下 (1957) 12) 等炕よつて夫心改 良せられ，耳硬化症の診断のみでなく，他の中耳伝音障 碍の検出にも育用されて来た. しかしこれ等の改良法む

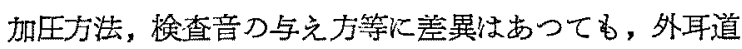

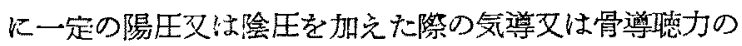
変化を測定するもので，原理的には同一のもの即ち，静 的加圧に上る Géllé 検查法 (以下清 $\mathrm{G}$ 法」と略す) とも云えるものである。

これに反し外平道圧を絶えず变化さした際の德力の变 化老測定する方法，即ら動的加王化上る Géllé 険查法 (以下 「動 $\mathrm{G}$ 法」と略す) とる云らべぎものについて
は当教空の内藤 (1948) 18), 191, 20), 辰巳 (1953) 21) 加静 $\mathrm{G}$ 法に比し優れた方法であると述べているが詳細な研 究は未だ行なわれていない，そこで著者はこの動 $\mathrm{G}$ 法 について更に詳細な研究を行い,この方法が簡単, 鋁敏 に伝音系の固着度を診断し得，原理的にる静 $\mathrm{G}$ 法と全 く粠なつた検查法であることを知つたのでこつに報告す る次第である。

\section{第 2 章 基礎的研究}

第 1 節 研究対象

阪大耳鼻咽续科教室員並びに着櫵婦で耳鏡㭘査で外耳 道及び鼓膜に常常を䍿めず純音聴力が気導骨尊共に正常 なるるの10名 20 耳を選んだ。

\section{第 2 節 研究装置}

大要を第 1 図炕示す。ポリッッエル球（以下ホポ球と略 す）に接続したがラス T 字管の一方に Tycos 型、， メーター（血圧計に使用しているもので 0〜 300 $\mathrm{mmHg}$ 最小目盛 $2 \mathrm{mmHg}$ ），一方に肉厚ゴム管を介し耳栓をつ ける、耳、栓はプシスチック整，外径夫た $7,8,9,10 \mathrm{~mm}$.

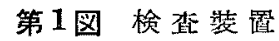

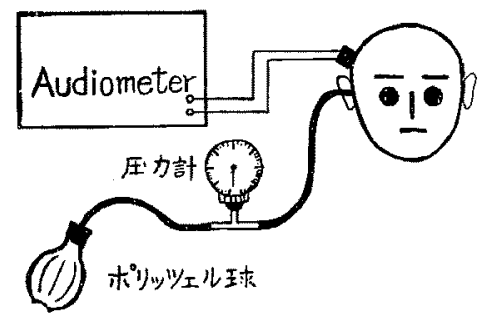

内径 $2 \mathrm{~mm}$ のもの 4 種を用意し被検者の外耳道孔の大き さにより適宜とりかえた。耳栓の外耳道插入部はゴムで 被い耳栓装着佶:の落痛を和らげ且外耳道管が可及的気密 になるようにした・外耳道圧は比較的短時間内に变化す るから，この気泌㢑は静 $\mathrm{G}$ 法程厳重にする必要はない。 検查音源として Atlas-Audiometer 及る゙その骨導子 学用い，250，500，1000，2000，4000cps の5 音について 検查した。

第3節 研究力法

動的加纴の一法として，著者は最も簡単な周期運動で 古る単振動を用いることにした。即ち被倹耳儿第 2 節で 述べた流置の耳栓を舫入し軽く圧迫保持也しめて，ポ球

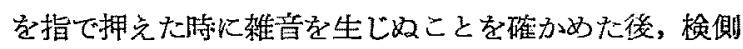

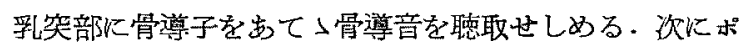
球を手指で周期的に押えたり離したりすると外耳道王仙 それ従つてほら゙正弦波的炕変化する。程球を拥える 
力を次第に強めて行くと，令迄連続的に聴古ていた骨 尊音が脈音となり初める。この㭙の外耳道圧の变動值 $(\mathrm{mmHg})$ を以て本検查法の陽転值ときめた。このよう な方法で，骨導羔の強さを關值上（耳栓による骨導上䒜

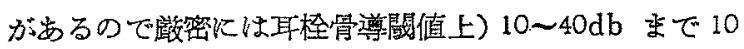
$\mathrm{db}$ 閒槅，加圧周期を毎秒的 1 回〜4 回迄变化さした時: の陽䎐値の变化を調べた.

第 4 節 研 究 成續

$250,500,1000,2000,4000 \mathrm{cps}$ の各倹查音についての 動 $G$ 法陽転值（20 耳の平均）第 1,2 表に示す. 但 し 250〜2000cps の間では同じ成績が得られたのでこれ を1つの表にまとめた。

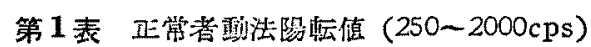

\begin{tabular}{|c|c|c|c|c|}
\hline \multirow{2}{*}{$\begin{array}{c}\text { 加圧周期 } \\
\text { (回/秒) }\end{array}$} & \multicolumn{4}{|c|}{ 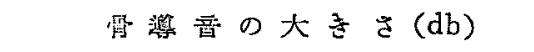 } \\
\hline & 10 & 20 & 30 & 40 \\
\hline 1 & $\stackrel{2}{2} \mathrm{mmg})$ & 2 & 2 & 2 \\
\hline 2 & 2 & 2 & 2 & 2 \\
\hline 3 & 2 & 2 & 2 & 2 \\
\hline 4 & 2 & 2 & 2 & 2 \\
\hline
\end{tabular}

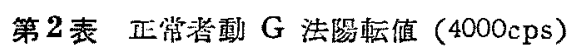

\begin{tabular}{|c|c|c|c|c|}
\hline \multirow{2}{*}{$\begin{array}{c}\text { 加圧周期 } \\
\text { (可/秒) }\end{array}$} & \multicolumn{4}{|c|}{ 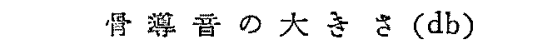 } \\
\hline & 10 & 20 & 30 & 40 \\
\hline 1 & $\begin{array}{c}10 \\
(\mathrm{mmHg})\end{array}$ & 8 & 8 & 8 \\
\hline 2 & 6 & 4 & 4 & 4 \\
\hline 3 & 6 & 4 & 4 & 4 \\
\hline 4 & 4 & 2 & 2 & 2 \\
\hline
\end{tabular}

第5節 小括

以上の絬果を琹約すると，250〜2000 cps 迄は骨樽音 の大ささ及如び圧周期炕閣係なく，全例共，纴力計の最 小目盛である。 $2 \mathrm{mmHg}$ て陽性となつた。 $4000 \mathrm{cps}$ で

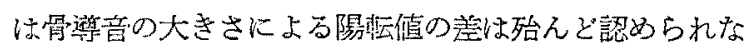
かつたが，扣圧周期が速くなるにつれ陽転值は小となる 傾问を示した。こ机については管4章沈いて述べる。

\section{第 3 章 臨床的研究}

前章に括いて述べた如く動 $\mathrm{G}$ 法により，正常者に括 いて一定の成續を得たので各種難聴者についても同樣の 研究を行ってみた。

第 1 節 榆查対象

炤和 32 年 8 月上り昭和 33 年 2 月迄の間に阪大耳鼻咽
喉科を訪れた難聴患者の中，感音䒺難聴 26 名 52 耳, 伝 音䒺難聴 94 名 145 耳計 120 名 197 耳について检查した。 第 2 節 検查装置 前章に述べた装置を使用

第3節 検查方法

既述の如く，正常者の動 $\mathrm{G}$ 法陽転值は骨導音の大き さ，加圧周期により大差が誌められぬ故，難聴患者の検 查に際しては骨導音の大きさ仅び加王周期をほら゙一定し た・即号骨導音の強さは患者の最も聞きやすい大きさで ある閧值上 30〜 40db とし, 加圧周期は手動て最も行い やすい上 $5 に 1$ 秒約 2 回とした、骨尊聴力の左右差が $10 \mathrm{db}$ 以上の場合怗，恥力損失大なる側検查の際反対側 は白色雑音で遮敞した. その他の操作は前節に述べた通 りである。

\section{第 4 節 㭘查成績}

第 1 項 感音䒺難德

耳鏡検查で異常る䜅めず純音俧力検查で気導骨導聴力 が同程度の障碍を示すもの 26 名 52 耳の検查成績を第了 表に示す. 但し聴力損失が大で閔値上 $30 \sim 40 \mathrm{db}$ の骨導 音が得られぬ陸沈 Andiometer 最大出力の骨導音使 用した。

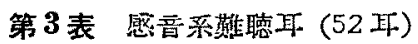

\begin{tabular}{|c|c|c|c|c|c|}
\hline \multirow{2}{*}{$\begin{array}{c}\text { 隄䛃時外耳道圧方 } \\
(\mathrm{mmHg})\end{array}$} & \multicolumn{5}{|c|}{ 骨㙙害周波数 (cps) } \\
\hline & 250 & 500 & 1000 & 2000 & 4000 \\
\hline 2 以下 & 49 & 49 & 49 & 49 & 49 \\
\hline $5 \%$ & 3 & 3 & 3 & 3 & 3 \\
\hline 㱚 (耳) & 52 & 52 & 52 & 52 & 52 \\
\hline
\end{tabular}

第 2 項 非空孔性中㷋

慢性中耳カタルで鼓膜陷凹があり耳管の通気度不良の もの，非空孔妵中耳炎等 25 名 41 耳の検查成績を第 4 表 に示した．但し鼓膜陥凹が強度で鼓寉壁々癒着せるもの

第 4 表 非穿孔性帆耳炎（41 耳)

\begin{tabular}{|c|c|c|c|c|c|}
\hline \multirow{2}{*}{$\begin{array}{c}\text { 探枟踩外叿道圧力 } \\
(\mathrm{mmHg})\end{array}$} & \multicolumn{5}{|c|}{ 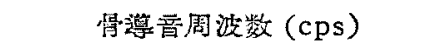 } \\
\hline & 250 & 500 & 1000 & 2000 & 4000 \\
\hline 2 以 $下$ & 18 & 15 & 12 & 15 & 15 \\
\hline 5 & 6 & 9 & 12 & 9 & 8 \\
\hline 10 & 12 & 12 & 11 & 10 & 11 \\
\hline 20 & 5 & 5 & 6 & 7 & 7 \\
\hline 飘 (耳) & 41 & 41 & 41 & 41 & 41 \\
\hline
\end{tabular}


○成䡠は別項に示すことにした。

第 3 項 穿孔性中耳炎

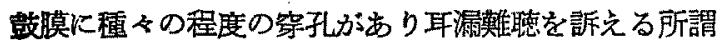
榎性穿孔性中耳炎の外に，鼓膜穿孔のみで耳漏なく中耳 粘膜の病変も著明でない乾性鼓膜穿孔も含めた 38 名 51

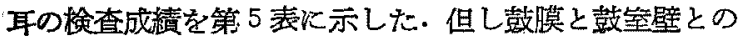
間に痖着のあるものは別項に述べることにした。

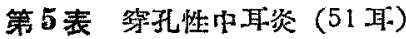

\begin{tabular}{|c|c|c|c|c|c|}
\hline \multirow{2}{*}{$\begin{array}{c}\text { 的院時外耳道圧力 } \\
(\mathrm{mmHg})\end{array}$} & \multicolumn{5}{|c|}{ 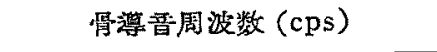 } \\
\hline & 250 & 500 & 1000 & 2000 & 4000 \\
\hline 2 W 下 & - & - & - & 一 & 一 \\
\hline $5 \%$ & 3 & 3 & 3 & 3 & 3 \\
\hline 10 & 9 & 7 & 7 & 8 & 8 \\
\hline 20 & 21 & 19 & 20 & 21 & 18 \\
\hline 40 & 18 & 22 & 21 & 19 & 21 \\
\hline $60 \%$ & & & & & 1 \\
\hline 計 (耳) & 51 & 51 & 51 & 51 & 51 \\
\hline
\end{tabular}

第 4 項 鼓膜狹着症

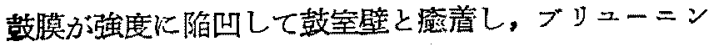
グス扰大耳镜で送気して委鼓膜に可動性の認められぬも の14名19耳の検查成續を第6表に示した。

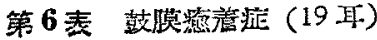

\begin{tabular}{|c|c|c|c|c|c|}
\hline \multirow{2}{*}{$\begin{array}{c}\text { 陽転特外耳道圧力 } \\
(\mathrm{mmHg})\end{array}$} & \multicolumn{5}{|c|}{ 骨浔潭周波数 (cps) } \\
\hline & 250 & 500 & 1000 & 2000 & 4000 \\
\hline 2 以下 & - & - & 一 & - & 一 \\
\hline 5 " & - & - & - & - & - \\
\hline 10 & 1 & 1 & 1 & 1 & 1 \\
\hline 20 & 2 & 3 & 3 & 3 & 2 \\
\hline 40 & 8 & 7 & 8 & 7 & 9 \\
\hline $60 " 1$ & 3 & 3 & 2 & 3 & 2 \\
\hline 60 以上 & 5 & 5 & 5 & 5 & 5 \\
\hline 飘（囥） & 19 & 19 & 19 & 19 & 19 \\
\hline
\end{tabular}

第 5 項耳硬化症

臨床所見，純音㯖力梌盉上り耳硬化应之猃断し，内耳 開空術により聴力改善の認められたるの17名34耳につ

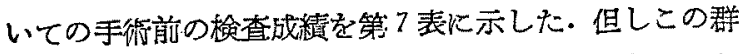
の患者は昭和 28 年 4 月より昭和 33 年 2 月迄のbのであ 万.
第 7 表 耳破化湴 (34 耳)

\begin{tabular}{|c|c|c|c|c|c|}
\hline \multirow{2}{*}{$\begin{array}{c}\text { 陽転時外耳道圧力 } \\
(\mathrm{mmHg})\end{array}$} & \multicolumn{5}{|c|}{ 骨導吾周波数 (cps) } \\
\hline & 250 & 500 & 1000 & 2000 & 4000 \\
\hline 2 以下 & 一 & - & 一 & - & 一 \\
\hline $5 \%$ & 一 & - & 一 & - & - \\
\hline 10 & 1 & 1 & 1 & 1 & 1 \\
\hline 20 & 1 & 1 & 1 & 1 & 1 \\
\hline 40 & - & - & - & 一 & - \\
\hline 60 & 1 & 1 & 1 & 1 & 1 \\
\hline 60 以上 & 31 & 31 & 31 & 31 & $31:$ \\
\hline 計（耳） & 34 & 34 & 34 & 34 & $34 i$ \\
\hline
\end{tabular}

第 5 節 小 括

以上述べた全应例の検查成績の虫 $250,1002,4000 \mathrm{cps}$ についての成續炎一括して篗 8,9,10表炡す.

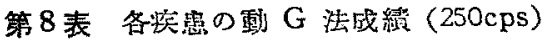

\begin{tabular}{|c|c|c|c|c|c|c|c|c|}
\hline \multirow{2}{*}{ 蚛 患 名 } & \multicolumn{8}{|c|}{ 陽転烓外耳道压力 $(\mathrm{mmHg})$} \\
\hline & 2 & 5 & 10 & 20 & 40 & 60 & $60 \sim$ & 霖 \\
\hline 感吾悉敬聴 & 49 & 3 & & & & & & 52 \\
\hline 非穿孔性相耳炎 & 18 & 6 & 12 & 5 & & & & 41 \\
\hline 穿孔性虾耳炎 & & 3 & 9 & 21 & 18 & & & 51 \\
\hline 鼓膜澺祸症 & & & 1 & 2 & 8 & 3 & 5 & 19 \\
\hline 耳硬化症 & & & 1 & 1 & & 1 & 31 & 34 \\
\hline
\end{tabular}

第 9 表 各笑患の檕 $\mathrm{G}$ 法成絽 (1000cps)

\begin{tabular}{|c|c|c|c|c|c|c|c|c|}
\hline \multirow{2}{*}{ 突 㭧 名 } & \multicolumn{8}{|c|}{ 陽呮持外耳道压力 $(\mathrm{mmHg})$} \\
\hline & 2 & 5 & 10 & 20 & 40 & 60 & $60 \sim$ & $(\text { 華 })^{+}$ \\
\hline 感㱏我澌聴 & 49 & 3 & & & & & & 52 \\
\hline 非穿孔性伹耷筷 & 12 & 12 & 11 & 6 & & & & 41 \\
\hline 穿孔性的聑炎 & & 3 & 7 & 20 & 21 & & & 53 \\
\hline 鼓膜藻宦症 & & & 1 & 3 & 8 & 2 & 5 & 19 \\
\hline 耳碓 化 批 & & & 1 & 1 & & 1 & 31 & 34 \\
\hline
\end{tabular}

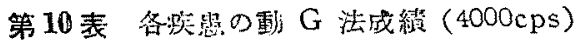

\begin{tabular}{|c|c|c|c|c|c|c|c|c|}
\hline \multirow{2}{*}{ 粉 虫 名 } & \multicolumn{8}{|c|}{ 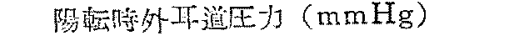 } \\
\hline & 2 & 5 & 10 & 20 & 40 & 60 & $60-$ & (5) \\
\hline 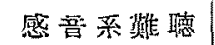 & 49 & 3 & & & & & & 52 \\
\hline 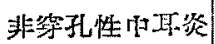 & 15 & 8 & 11 & 7 & & & & 41 \\
\hline 穿孔性闯聂炎 & & 3 & 8 & 18 & 21 & 1 & & $5 \mathrm{~L}$ \\
\hline 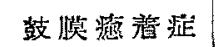 & & & 1 & 2 & 9 & 2 & 5 & 19 \\
\hline 耳碓化跑 & & & 1 & 1 & & 1 & 31 & 34 \\
\hline
\end{tabular}




\section{1) 臨音系難聴}

52 耳中 49 耳は正常者と同橡 $2 \mathrm{mmHg}$ 以下で陽性と なり残りの3耳西 2〜 $5 \mathrm{mmHg}$ で陽性となつた。

2) 非穿孔性中聑炎

この群では一般に聴力障碍は軽度のbのぶ多く、動 $\mathrm{G}$ 法の陽転值も $20 \mathrm{mmHg}$ 上り大となる例はなかったた。 しかしながら聴力損失と隄転值との間に一定の関係は認 められなかった。

3) 穿孔性中耳炎

この群には陽鞋值が正常者に近いるのとしからざるも のともる.前者は臌膜穿孔のみで中耳は乾燥し粘膜の病 変も少小もので㯖力損失は軽度である。後者は鼓膜穿孔 のみでなく中耳粘膜の肥厚，耳漏等のある所謂慢性穿孔 性中耳炎で㯰力損失む $40 \sim 60 \mathrm{db}$ に及ら゙すのである. このよ5な例では動 G 法は各周波数において 20〜40 $\mathrm{mmHg}$ のるのが大部分を占めるが耳鏡検查による中耳 病変の程度あるいは聴力損失との間には一定の関係は諗 わられなかつたが，この陽転值が $40 \mathrm{mmHg}$ をこえ るるのはわらか1例ですつだ

4) 鼓膜瘜着症

一般に陽転值は大で $40 \mathrm{mmHg}$ 以上のものが 19 耳中

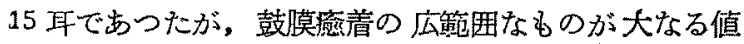
をとるとは限らなかつた。これ怯後述の如く贈 $\mathrm{G}$ 法が 裁膜の可動性のみに影響されるのでなく，耳小骨連鎖の 機能とも関係するためであるら。

5) 耳硬化症

伝音系難㯖の中でも最も大きい值る示し 34 耳中 31 耳 は $60 \mathrm{mmHg}$ の区変動でも陽転しなからた・

以上の成續から，著者の行つた動 $G$ 法による伝意機

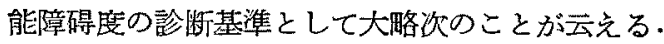

1) 陽転值が $5 \mathrm{mmHg}$ 以下であ机ば层意系はは心゙正 党である。

2）陽転值が 10〜20 mmHg のものは伝音系の軽度 陪碍.

3）陽転值方 30〜 $50 \mathrm{mmHg}$ 多のは伝音系の 中等度 辤碍.

4) 陽転值が $60 \mathrm{mmHg}$ 以上のものは伝音系の高度 障㥂である。

\section{第 4 章 Géllé 現象の成立機転について}

外耳道に一定の 壬力を加党た際骨尊聴力が低下する (静的 Géllé 現象) 原因については従来二つの見解があ

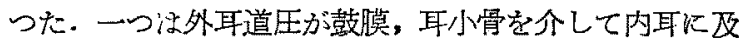
び、内耳压が旮進して感覚細胞の感度が低下し，ために
聴力が悪化すると云う説であり，他は加圧により中耺 音采の Impedance が増加し，骨尊成分中の骨鼓室伝導 が不良となり聴力が低下すると云5説である：しかし近 年 Wever 等 (1942)22) の研究により，加圧による㯰为 の低下は大部分が中耳の Impedance の変化によるも のと云ら説が一般に支持されている.更に恩地 (1954) は耳栓骨尊に閔する研究の中で, Géllé 現象についてい 研究しその成立機転を明らかにした。即ち「耳栓により 増加した鼓膜の振幅が加圧により減少するため兴尊聴力

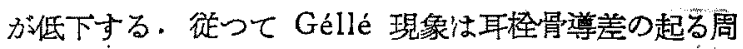
波数篹囲においてのみ現れ，その閔值上昇む外耳道開放

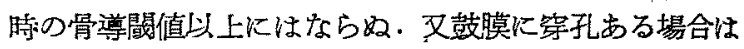
外耳道加圧は穿孔を通して中耳の空気に及ら゙から鼓膜内 外の気圧は等しくなり故膜の振動を抑制することはでき ず Géllé 現象は現うれない.つまりGéllé 現象は影膜 の Impedance の変化によつて影響されるため鐙骨固着 の及の検出洷でない.」と述べている。これ等の研究は すべて静 G 法による聴力低下についての研究である。

而るに著者の行つた䖝 G 法による Géllé 現象は静 G 法により起る Géllé 現象と異なつた性質を有する.

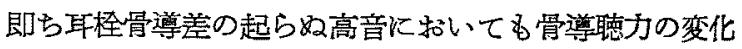
は明らかに翟められ，又鼓膜彁孔耳でも聴力障碍が軽度 であれば陽転值は正常者に近い值を示す。このように静 $\mathrm{G}$ 法と動 $\mathrm{G}$ 法が異なつた成續を示すので, 著者はその 蒠因家追求するため以下の如き考察を試外た。

第 1 節 加王方法に対する考察

人間の最低可聴周波数は約 $20 \mathrm{cps}$ でありこれ以下 では皮膚に触覚として感ずるのみで音としては感しない と云われている ${ }^{23)}$. しかし 20cps 以下の低音でる空気 の振動と云う点で本筫的には相異のないるのであるから 耳火対して，より高い音と同じような影暃を与えるるの と若壳られる。

Békésy (1934) 24) はゆつくりした周期の空気振動の

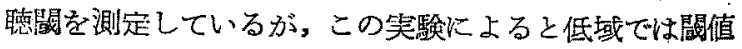
が急速に上昇し $2 \mathrm{cps}$ では約 140db の音圧で聴覚を起 まと述べている(第2図).

著者の行つた動 $\mathrm{G}$ 法に括いて外耳道圧を2 $\mathrm{cps}$ の周 斯て変動さした場合，正常者の陽転值は約 $2 \mathrm{mmHg}$ て あるが，これる音压に換算すると約 $140 \mathrm{db}$ となり Békésy の笑駺炕よる 2cps の闘值とほよ゙一致する.

このようなことから，外耳道王を毎秒 2 回の割合で正 弦波的に变朗さすと云らことは，耳に $2 \mathrm{cps}$ の純音を与 えたものと考えられ静 $\mathrm{G}$ 法の如く外耳道に一定の圧を 
第 2 図 低吾の聴閜（Békésy 1934）

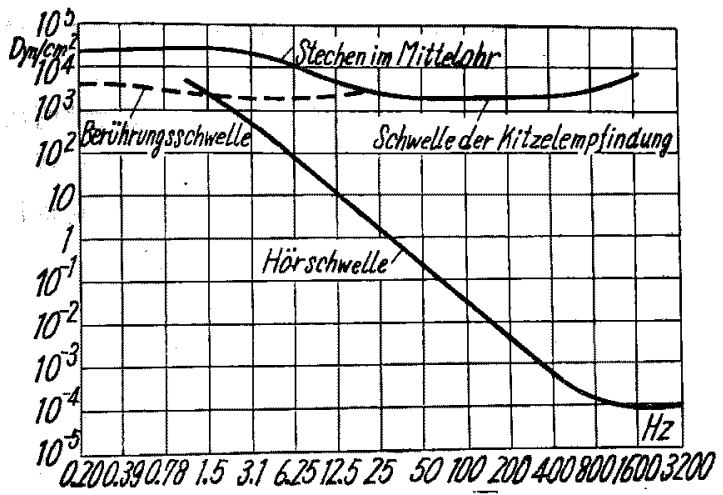

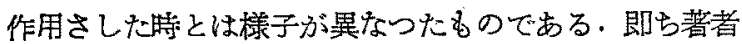
の動 $\mathrm{G}$ 法忙気導によつて 2cps の音を，骨導によつて 250〜4000cps の音を与充, 気尊意の強さにより骨導音 がどのように影響されるかを検查する方法である。

第 2 節 外耳道仕の変動㴍式々骨導聴力变動 㴍式との関係

被検者として鼓膜に 所見なく聴力正常なるの10名 10 耳を選んだ、検側乳突部に学尊レシーバーを当て閶值上 $5 \mathrm{db}$ の音をきかしながら，外耳道圧を正弦波状攻び階段 状に変化し，各ふの場合の骨尊音の大きさの変化を図示 せしめた。結果第 3 図に示方。

即ち外耳道㘴を約 $2 \mathrm{cps}, 2 \mathrm{mmHg}$ で正弦波的に変動

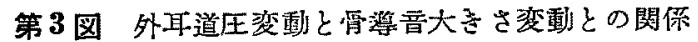

(a) 外耳道圧変化 約 $2 \mathrm{cps} 2 \mathrm{mmHg}$

(c) 同 $0 \sim 15 \mathrm{mmHg}$ 迄 $3 \mathrm{db}$ 宛隙 段状に变化

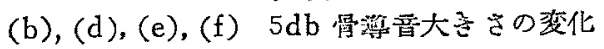
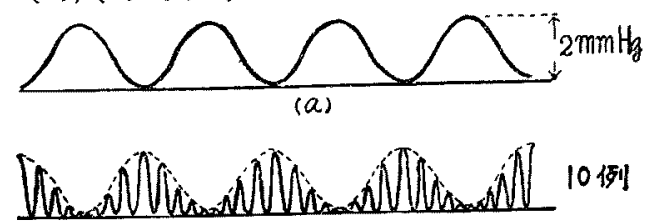

10 例

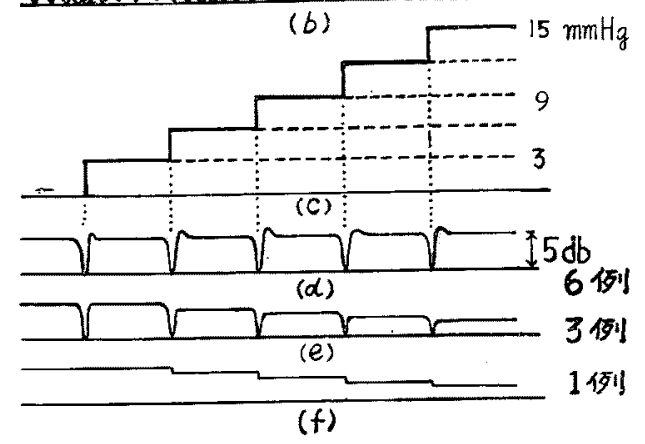

さすと,骨尊音は 10 例共丁度王变動の周期で変調された 脈音として感ずる.今外耳道圧变化の周期を $\mathrm{f}_{1}$, 骨導音 の周波数を $\mathrm{f}_{2}$ とするとこの場合生じた脈音沙 $\mathrm{f}_{9}, \mathrm{f}_{:}$$\mathrm{f}_{1}, \mathrm{f}_{2}+\mathrm{f}_{1} ，$ の三つの周波数の合成されたるのであること はよく知られている. 即ち $f_{1} ， f_{2}$ の二つによつて生ず る複合音の一種である $f_{2}-f_{1}, f_{2}+f_{1}$ なる成分が含まれ ている。

耳に周波数の異なつた2 音 $\mathrm{f}_{\mathrm{il}}$ ， $\mathrm{f}_{\mathrm{b}}$ を同持に聞かした 場合，原音と全く異なつた周波数の複合音が生ずること は既に Sorge (1774), Tartini (1754) 等によつて観察 されて和り，又その周波数は $\mathrm{mf}_{\mathrm{a}} \pm \mathrm{nf} \mathrm{f}_{\mathrm{b}}$ て現わされ， 㯖器の非直線性至によつて起るものであるここが Helmholtz (1856) kよつて理論的にも解明されている. 外耳道王を正弦波形的汇変化さした場合この空气振動々 骨導音との間に聴器の非直線性歪による複合音が生ずる とすれば耳には原音の他にこれ等の複合音が聞劣るわけ である・だ゙この場合 $\mathrm{f}_{\mathrm{b}}$ に相当する周波数注 $2 \mathrm{cps}$ で あるため音として感じ難く $f_{a}$ に相当する骨導音及びそ の第一次複合音である $f_{a}-f_{b}, f_{a}+f_{b}$ が主となり，こ れ等が脈音となつて聞えるのであるう。

次に外耳道王を $3 \mathrm{mmHg}$ Step 階段状に上等した場 合。骨導音の大きさは圧が变化する部で著るしく小さく なるが，压が定常状態になると骨導至将加圧前の大きさ にもどるもの (6 例) 加压前より少し小さく感ずるもの

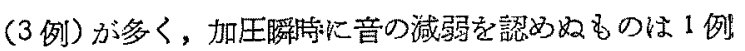
であった・

外耳道加止による骨導音の減弱が中耳伝音系の Impedance の变化によるものであれば，階段状に圧を変化 さした場合骨導音も階段状に減弱する筈である・故に図 の如く加圧瞬持に見られる著明な骨尊音の戚弱は中耳性 のものと㛈えられず恐らく内耳に起因するものであろ 5 .

第 3 節 聴器の歪について

耳に純音を聞かした場合原音に含まれない高調音や複 合音が聞えるのは前述の如く眲器の雨によるるのである が，その發生部位についての研究は数多くなされてい る.

Dahman (1929), Kobrak (1948) は外耳道加圧時つ 鼓膜の偏位分娍壬時つ偏位より小な所から垔音の発生を 鼓膜に求めている・しかしこの実騒に用いた压力は極め

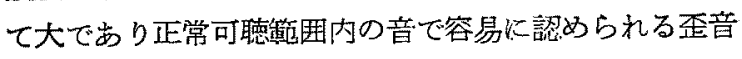
を説明するには不十分である. Békésy (1934) 汭)の干 涉管を用いた害騃によ机ば，鼓膜においては歪音は殆ん 


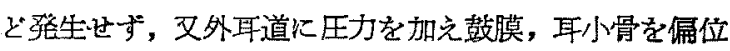

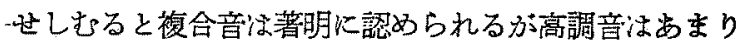
变化しない。この事から彼は複合音は主として耳小骨連

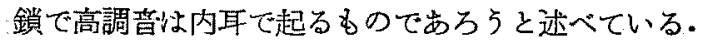

しかしはがら Dennert (1887), Bingham (1907), Lewis \& Reger (1933) 等虫中医雭て鼓莫や耳小骨

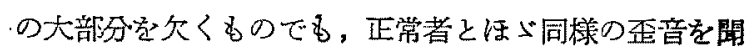
くことから聴器つ昰ぶ中耳のみ起区するものでないと 嗵べている. Wever, Bray \& Lawrence (1940, 1941) 27) 97 28) 29), Wever \& Lawrence $(1954)^{31)}$ 《恥器の

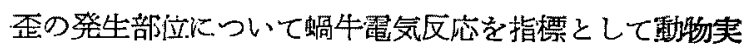

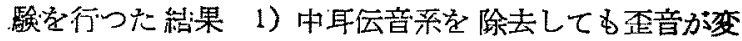

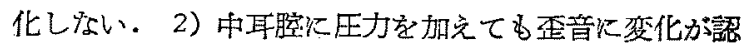
められない３）刺战篦を強くした場合内耳に伝わつた

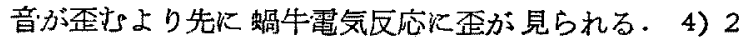

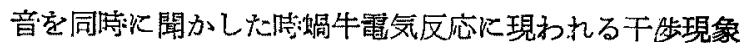
(Interference) は雪竟発生のために原音のェネルギー が消費されて起るるのでありここの干涉現象は感覚細胞

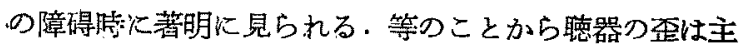
として内耳の感覚袖㖒の所火西ると結諭した。

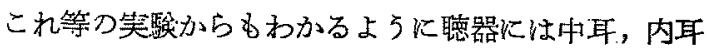
共に歪を有して敊り，就中何に拈ける歪の方が大き

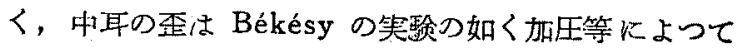
振動の状態を变化した際認めやすくはるものと考えら

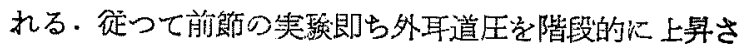
した場合，加圧瞬棤：認められる骨導音つ著明な減弱は 内耳歪に起因するすのであり，压方定常状態になつた時

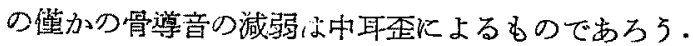

第 4 節 䒠娩的伝音系難聴耳と動 $\mathrm{G}$ 法

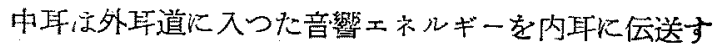

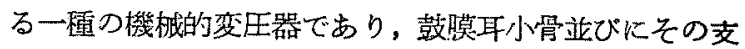

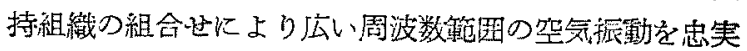

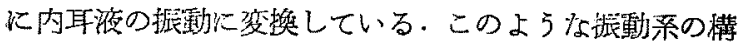
成組織を単なる物理的なるのと考学れば，数式的にそ の動作を理解すること可能で市る，古くは Frank (1918，1923) k始末り Johansen (1948) 31) 因地(1949) 32) Wever \& Lawrence $(1950,1954)$ 3n) 33) Zwislocki

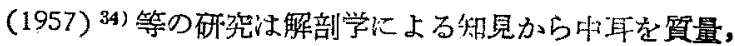
弾阵，摩擦つ三要素の組合せ《よる振動系と考光，その 特泾を数式的に解明しているるのである。

一般にこのような振動系は質量のみが增加すれば高音 の㐾送能染が不良となり，弾性つ夕增加すれば低音の伝 送能率が悪化する・そこで著者沈人工的に中耳に負荷を
与えてその質量又は弾性のみを增加さした場合，動 $\mathbf{G}$ 法の值ゔどのように変化するかる謂べて見た。

1）伝音承の貿悬を堷加した場合

鼓膜面上に鉷文液体を負荷すると鼓膜つ貿量は增加 L高音鿵力ふ低下する. (Bárány 1909 35), Runge 1923 3), Lüscher 1939 3i) 広瀨 19573 )）第 4 図性鼓膜国上

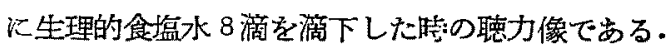

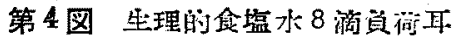

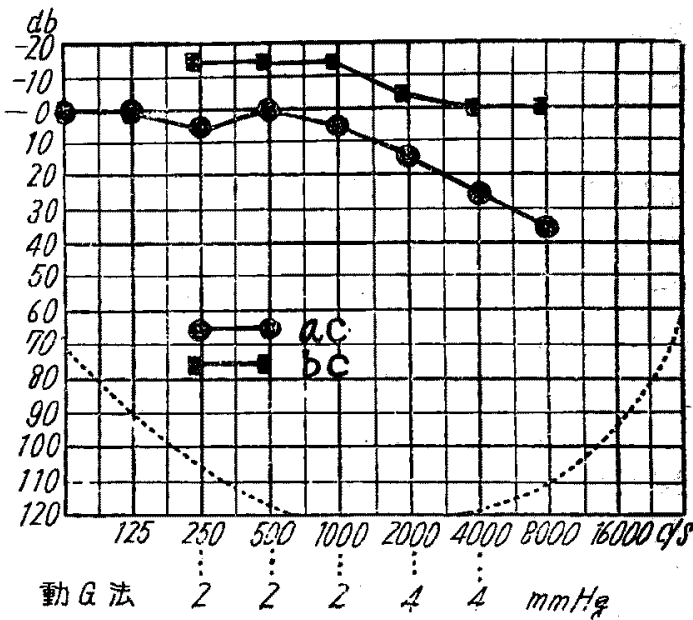

滴下前の気尊骨導聴力を Odb とすると，滴下後気導 聴力は $1000 \mathrm{cps}$ 迄は殆えど变化なくそれより高音で 周波数が高くなるにつれ疅力損失が增加している。一方 骨導聴力は耳柽骨導と同様 250〜2000 cps の間に 15〜 $5 \mathrm{db}$ の閶值下降が見られる。

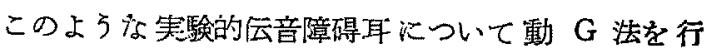
つた結果 250〜4000 cps の搝査至で陽転值はすへて 4 $\mathrm{mmHg}$ 以下であり正常者に近い值を示した。

2) 伝音系の弾制を堛加した場合

奏験的に质音杀の弾性を增加さすため第 5 図の如くク リスタルレシーバーの振動膜を取䋡きその代りに薄いフ ルミ管を張つたものを作成し使用しだ ${ }^{39}$ 。

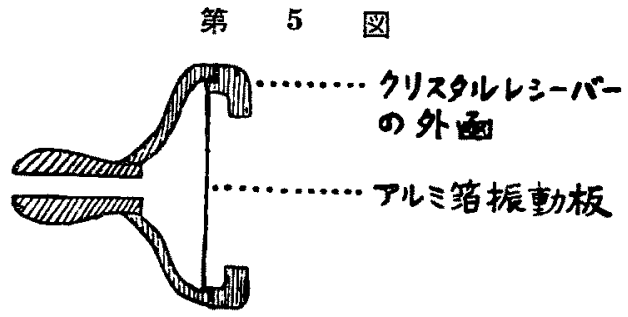


第6 6 図はこのレシーバーを外耳道汇装着した㭙の聴力 像である、レシーバー装着前の気尊骨導聴力を $\mathrm{Odb}$ と すると装着後の気導聴力は弾性增加のため $4000 \mathrm{cps}$ 上 り低音火なるに従つて聴力損失が増加している．8000

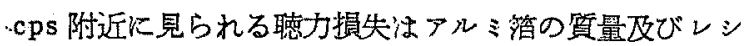
一バー装着による影響によるるのと考えられる。一方骨

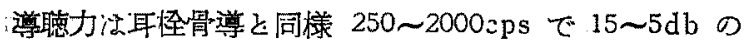
闎值低下が見られる。

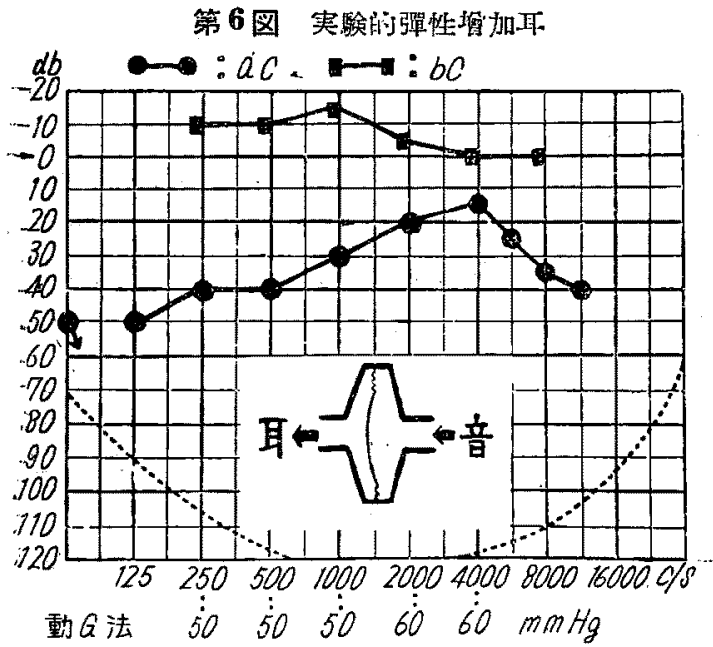

第 1 図の装置の耳栓の代りにこのレシーパーを取り付

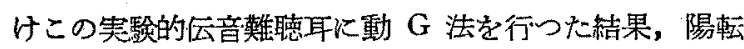
值仼非常に大きく 250 4000乞ps の各検查音で 50 60 $\mathrm{mmHg}$ であつた.

この実䍄からもわかるように伝音䒺難聴耳でも質量の みの増加で低音の聴力損失がない脚は 2cps の压変動は 正常耳の場合と同じ程度で内耳火達するため動 G 法陽 転值は小であり，反対て弾性の堌加により低音の聴力損

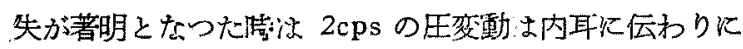
く〉, 往つて動 G 法陽転值む大となると考方られる. 即ち $2 \mathrm{cps}$ の圧変動引汭耳立伀送される程度に上り動 $\mathrm{G}$ 法つ値が变化して来る。

\section{第5 5 節 小 括}

以上述べたことから著者の行つた動 $\mathrm{G}$ 法を原理的に 考えて見ると，骨尊で腫々の周波数の検查音聞かしな がら外耳道に約 $2 \mathrm{cps}$ の空気振動を与光ここの二つが内 耳歪により複合音を生じ脈音として感じられるのを検查 する方法一換言すれ诂内耳歪を利用し $2 \mathrm{cps}$ の如く, 一音のみでは認め難い低音の 伝送能力を湘定する方法 と云克る．この場合第 2 图からもわかる如くこのよ5
な低音の伝送能力は周波数による美が大であるから動 $\mathrm{G}$ 法の陽输值む加圧周期火より翼なるべきである：第 2 章の正常聴力者の成績で $4000 \mathrm{cps}$ の検查音で動 $\mathrm{G}$ 法陽 転值が加代周期が早くなる汇つれ小となる傾向を示した のはこのためで古万弓．但し 2000cps 以下ではこの㑯 向が見られなからたのは，二音の周波数がより接近して いるため加圧周期が痋くとも雪が起りやすいものと考え られる (Békésy (1934) s5)).

低音の伝送能力は主として中耳の彈性炕よつて左右さ れるから動 $\mathrm{G}$ 法俚中耳伝音系の弾性の大小を示し, 從 つてその固售の程度を測定し得るものでらる。

\section{第 5 章 考按}

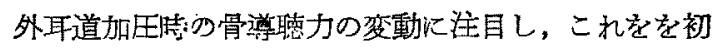
わて難聴の鑑別郝断に応用したのは Géllé (1881) であ る. Thullen?によれば「この検查はポリッッェル球と 外耳道とを気密のゴム管でつなぎ, 音の鳴つている音叉

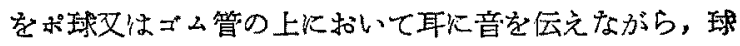
を押して外耳道に压を加えた㭙の音叉音の変化を調べる

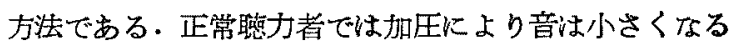
が鐙骨固着がある場会は音が不変である」と述べてい る。

しかしながら Géllé の原法では外耳道を気密にする ことが困難であり，又出力が減衰する音叉音源として 用いるため正確な測定が困難であるとの理由から，多く の改良法が考按された。

Griessman (1921) 愔源红 Audiometer 用い, Pneumatic Telephone で外耳道に一定圧を加觉た封 の聴力を剆定し, 正常耳で加瓜とより㽪力は低下する が減圧で㳄不変であると述べている.

Dishoeck (1938～39) 19) 15) は外耳道圧を正確汇加城 し得る Pneumophone を考按し，この装置を用いて正 常聴才者及び難聴者つ外耳道生を $+30 \mathrm{mmHg}$ から $30 \mathrm{mmHg}$ 迄徐々に変化さし最る聴力がよい点を測定し た. 正常聴力者ではこの圧は $-2 \sim+2 \mathrm{mmHg}$ の籍因 であるが耳筲閉塞定患者では -10〜 - 30 $\mathrm{mm} \mathrm{Hg}$ であ り, 中耳腔圧と外耳道圧が等しい呫沉最もよい恥力が得 られると述べている. 更にこの検查では鼓膜窎孔耳や耳 硬化症耳では最も聴力の上い点敒認められず耳硬化症診 断の一助として Géllé 检查法より磪笑であると述べた。

Rasmussen $(1946,48)$ 16) 1i) は Dishoeck $の$ Pneu-

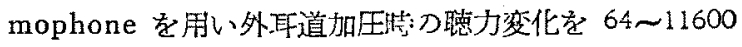
cps の広い範围にわたり観祭した。正常耳及び耳硬化应

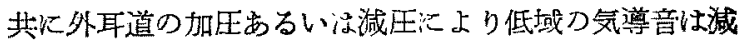


弱するが $4000 \mathrm{cps}$ 上上では一定の成續を得られなかつ た.一方霄遒音の場合正常者は気導の場合と同栐の結果 を得たが耳硬化症では音の大ささに変作はなかつたと述 ベている.

Thullen (1954) 方) は外耳道胵を完全に気密にするた め特殊な耳柽を考按し，これを用いて加仕及び減王時の 聴才変化を測定した，正常者，感意采難聴，耳管閉塞

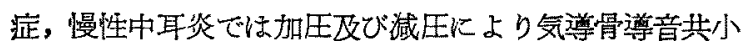
さくなるが，耳硬化症，鼓膜揄着の場合は音の大きさが 不変であることを観察している.

松下 (1957) 12) は Thullen と同檥の方法を各種難恥 患者に応用し 2 $19 \mathrm{mmHg}$ の加生で骨導音が減弱する 場合恃伝音采性殆んぞ正常であり，20〜 40mm $\mathrm{mg}$ のも のは伝音器の可動性に 軽度の障碍あり，40 $90 \mathrm{~mm} \mathrm{Hg}$ のものは中等度の障碍，100〜160 $\mathrm{mmHg}$ の加纴でも音 が小さくならぬすのは伝音糸の完全固着と述べている.

しかしながらこれ等の Géllé 改良法は原法を誈まり て解釈しているものと考支られる．何故なら前述の如く Géllé 原法は加圧にポ球を用い，検查音源として出力が 㳦衰する音攴を用いている。このような装置ては外耳道 压を一定に保つことは困難であり市たと充を一定にし 得たとしてる検查音が次第に減衰するため，被検者はそ

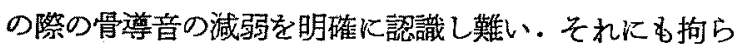
す正常者と耳硬化症患者で明らかな差異を認め得たの は，外耳道を加圧した瞬間の音㕛音の变化に注目したる のてむろら．この上うな㭘查法は明らかに動的加生法で あり，その後の改良法である静的加压法とは異なるもの である。

このよ5な見地から著者は動的加圧法の一つとして， 外耳道压を正弦波的に变動させ，同時に聴取させた骨導 音が脈音となるに要する珐力を湘定する方法を考按し た・そしてこの方法により各種難聴者を検查した綃果， 伝音，感音難聴を鑑別し得るのみならず，伝音系の固着 度をある程度量的に测定し得，特に耳硬化症の諪断に有 益であることを知つた。

即ち正常聴力者及び感音系難聴者では全例 $5 \mathrm{mmHg}$ 以下で動 G 法が陽性となつた。一方伝音柔難聴耳では 鼓膜の小穿孔あるいい症痕のみで聴力損失が軽度のもの では動 $\mathrm{G}$ 法は 5〜10 mmHg のあのが多く、止硬化症 耳では大部分が $60 \mathrm{mmHg}$ でも陰恎であった。しかし ながらその他の伝音彔難聴はこれ等の中間值を示し，そ の純音聴力損失との間に一定の 䦭俰は認められなかつ た.
Fowler (1928) 39) は中耳满変と㯖力像之の関伱を物

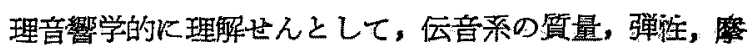
擦の变化が中耳のいかなる病変に際し生ずるか, 又これ 等の変化と聴力像との間にはどのような橍係があるが ついて論じている・即ら原則的には質量が増すと高音障 碍を生じ，弾性が堌すと低音障碍が生ずべきである。臨 床的には桘骨柄に耳垢が附着したり，鼓膜の肥厚や石在

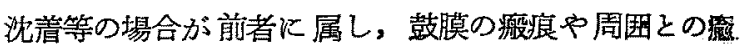
着, 鼓窒小骨との中耳骨壁との瘉着や鐙骨底周囲の知带 の骨性化等が後者に属すると述べている。

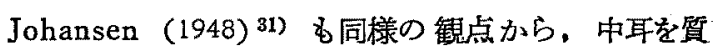
量, 弾性, 摩察の三要素の組合せたよる単一振動杀と考 え，中耳の等価回路を考按している。そして各要素が夫

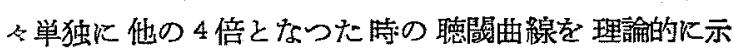
し，急性中耳炎の㭙汇見られる高域障碍はこの曲線中の Mass-curve k類似し，耳硬化症の初期に見られる低域 損失は Stiffness-curve に類似すると述べている。

しかしながら笑際には質量，弾性あるいは摩祭が各々 巣独に变化するような病変は少く，伝音柔疾患で種々 の聴力像を示すものである。著者の行つた動 $\mathrm{G}$ 法忙 2cps の如く遲い、周期の 空気振動の伝送能力を䋡查する 方法であり，その陽転值は主として中耳伝音系の弾柱の 変化によつて左右されるものである。佂つて伝音系疾患 の場合に種なの陽転值をとり，又質量や抵抗の变化によ

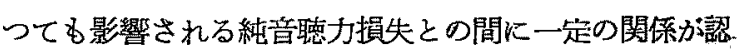
められめのも当然と考えられる.たら耳硬化症の如く伝 盖系の一部が骨性強直をきたすよ5な場合は弾性の増加 が著明であるため、動 G 法の洒が㮌めて大きくなるの であるう。

内耳閏空術が耳硬化症のみでなく，鼓膜や耳小骨の強 度の答着の場合にる適応して效果あることが判明してい 万現在（堀口 1953）40）伝音系の固着度を測定する動 G 法はこの点からあ與味方る検查法である。本检查法の陽

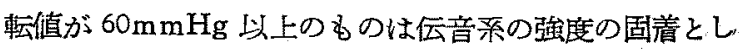
て内耳開空術も考克られる。

単純な純音聴力検查以外に伝音䒺難聴を診断する検查 法としては，前述の Géllé 原法及びその敳良法の外 に, 液体荷重法 (Bárány 1909 35), Runge 1923 3), 広賴. 1957 37), 角田 $1954^{10}$ )), 耳烃骨導検查法 (Pohlman \& Kraz 1926 41), Kelley \& Reger $1937^{42)}$, Sullivan, Gotlieb \& Hodges ${ }^{43)}$, 恩地 (3), 6), 7), 8), 液導穃榃法 (角田 1956 11))，音消息子法 (Pohlman 1948, Zöllner 1951 45), 戸谷 1954 4(1) Thullen 1955 47), 伝音 Impeda- 
nce 測定法 (Békésy 1939 48), Metz 194649), Jepsen

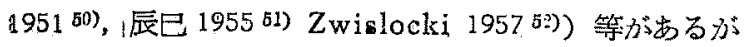
検查法が繁椎乃至は特殊な积査装置を必要とするため， 恩地の耳栓骨導䖽查以外は一般に底く応用される段階に 迄達していかい，しかしこの恩地法は伝音系難聴の有热 性診断し5るがその障碍度を判定し得奴欠点がある。例 えば第 7 図に示す如く乾性鼓膜穿孔により軽度の聴力障 碍のむる例で恩地法は㓌性であり，文往来の静 $\mathrm{G}$ 法 も陰性となる・しかるに著者つ動 $\mathrm{G}$ 沈では $5 \mathrm{mmHg}$ 踢性となり正常者:近い值を示寸.

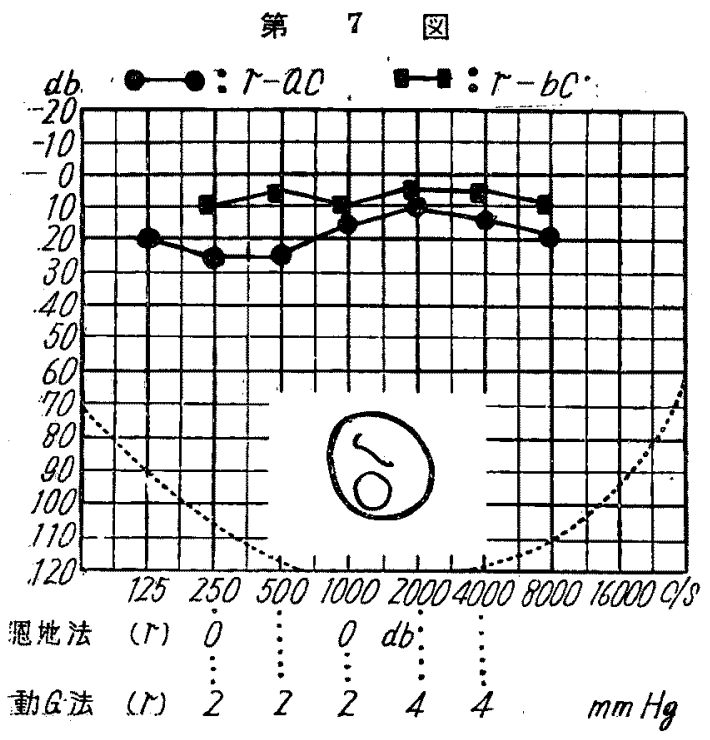

以上述べた如く動 $\mathrm{G}$ 法㳂羔感晋難㯖を鑑別し得る の欢でなく伝音梁の固着度をある程度量的に測定し得特 儿耳硬化症の曑断に便利な方法である。更にこの検查法

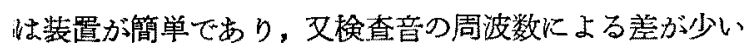
から実祭検查する際る $1000 \mathrm{cps}$ 一音のみについて行克 ば十分であり日常履床で容易に施行し5るあのと考克る 次第である。

\section{第6 章 結語}

耳硬化症の診断法として有名な Géllé 䖽查法につい て䄼到し次の如き結果を得无。

1) Géllé 㭲查法を加生方法により静的 Géllé 検査 法と動的 Géllé 検查法の二つに大別した。前者は外耳 道に一定の圧力を加えた状態の聴力变化を測定するるの であり，後者は外耳道压を絶えず変化さした際の聴力変 化を測定する力法である。

2）動的 Géllé 倹查法の一法として著者は外耳道圧
を約 2cps の制合で正㹡波的に変化させ，同掅厄聴取さ

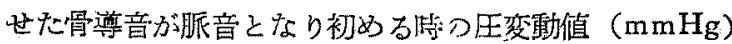
を求める方㳙を洘按した。

3）このう法で正常者及び各腫難聴者を検查し次つ如 き結果を得た。

i）正常者及び感音采蜼聴耳では圧変動值は $5 \mathrm{~mm}$ Hg 以下で涩つた。

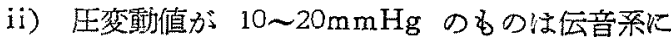
軽度つ固着があるるのと思われた。

iii）圧变動值が 30 50 $\mathrm{mmHg}$ のbの位音系に 中等度の固着があるるのと思われた。

iv）王变動值が $60 \mathrm{mmHg}$ 以上のるのは盾音系に 強底の固着があるものと思われた。

v）以上の結果は検査音の強さ及び周波数により大 善なからい。

4）外耳道圧の正泣波的变動により骨導が脈音となる 原因について考察し (第 4 章)，これが内耳の非踹線奀 炕よるるのであると考えた。

5）従つて著者つ検查法は内耳歪を利用し中耳の低音 伝送能打を测定し，これによつて伝音系の固萻度を調へ るむのである。

6) Géllé 検龺の原法次一種の重的加生法に属し，そ の俊の改良法は静的加圧法儿属するものであり両者の强 查法は原理的に全く異なつたるのであると栲えれ。

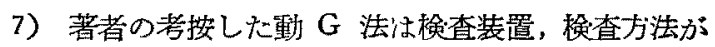
簢単で日常臨床に容易纪応用し得るものであり特汇耳硬 化症の䛦断便利な方法である。

\section{参考文 献}

1) Géllé: Transact. of Med. Cong. \& Cong, \& Sess. 3; 370, 1881, Thullen, A.: Arch. Ohr usw. Heilk. u. Z. Hals usw. Heilk. 164;382, 1954. \& v洞用 2) Bing: Mschr. Ohrenheilk. 33; 149, 1899. Runge, H.G.: Ueber die Lehre von der Knochenleitnng und uber einen neuen Versuch zu ihrem weiteren Ausbau Z. Hals-usw. Heilk. $5 r$ 289, 1923. 4) Campbell, E.H. \& Macfarlan, D.* Test Findings Before and After Fenestration of the Labyrinth Arch. of Otolaryng. 47; 595,

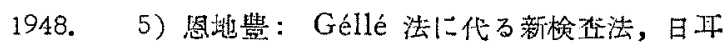
舅，54；102,1951.6）恩地豊：耳硬化狱の䛦断に

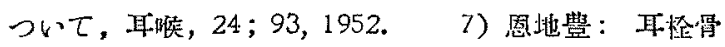

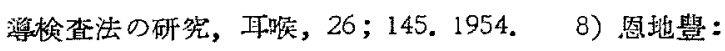

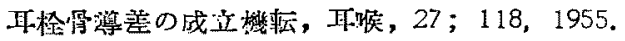


Thullen, A.: Diagnostische Erfahrungen mit Hörmessung bei variierten Druck im Gehörgang. Arch. Ohr usw. Heilk. u. Z. Hals usw. Heilk.

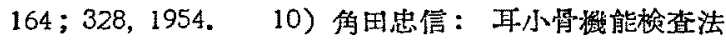

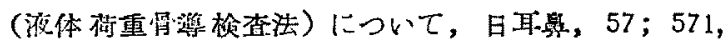

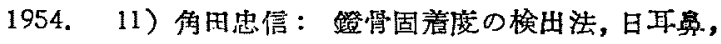
$59 ； 1939,1956.12 ）$ 松下草苗：意伝県系の可動性

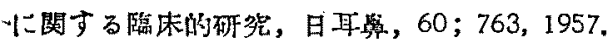
Griessman, B.: Neue Methoden zur Hörprüfung Passow-Schaefer's Beit. z. Anat. Physiol. des Ohres 16; 47, 1921, Rasmussen, H.: Acta Oto-laryng. 34；415，1946. 上り引朋 14) Dishoeck, H.A.E. van: Ein Apparat zur Druckbestimmung im Mittelohr Arch, Ohr-usw. Heilk. 144; 53, 1938. 15) Dishoeck, H.A.E. van: Theorie und Praxis des Pneumophons. Arch. Ohr-usw. Heilk. 146; 5, 1939 . 16) Rasmussen, H.: Studies on the Effect upon the Hearing through Air Conduction brought about by Variations of the Pressure in the Auditory Meatus Acta Oto-laryng. 34; 415, 1946. 17) Rasmussen, H.: Studies on the Effect on the Air Conduction and Bone Conduction from Changes in the Meatal Pressure in Normal Subjects and Otosclerotic Patients Acta Otolaryng. Supol. 74; 54, 1948. 18) 丙藤缶, 河剂良 光：外耳道気圧の变化と德力との閣傢について（第 1

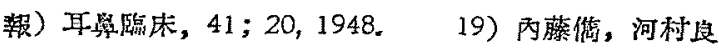

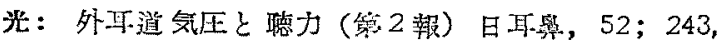

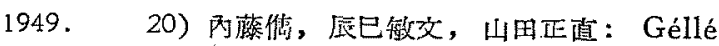

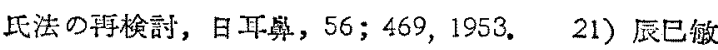
交，伊藤弘：Géllé 比侩查法の梌討，日耳舅，58;782， 1955. 22) Wever, E.G., Bray, C.W., \& Lawrence, M.: The Effect of Pressure in the Middle Ear J. Exper. Psychol. 30；40, 1942，23）黑木総一 郎：聴賞の心理学，共立出版社，聚京 1957.24 ) Békésy, G. von: Ueber die Hörschwelle und Fühlgrenze langsamer sinusförmiger Luftdruckschwankungen Ann. d. Physik 26;554, 1936 . 25) Békésy, G. von: Ueber die nichtlinearen Verzerungen des Ohres Ann. d. Phsik. 20; 809, 1934. 26) Wever, E.G., Bray, C.W., \& Lawrence, M.: The Origin of Combination Tones J. Exper. Psychol. $27 ; 217,1940$. 27) Wever, E.G., Bray, C.W., \&
Lawrence, M.: The Locus of Distortion in the Ear J. Acoust. Soc. Amer. 11; 427, 1940. Wever, E.G., Bray, C.W., \& Lawrence, M.: The Intrference of Tones in the Cochlea J. Acoust. Soc. Amer. 12; 268, 1940. 29) Wever, E.G., Bray, C.W., \& Lawrence, M.: The Effsct of MiddleEar Pressure upon Distortion J. Acoust. Soc. Amer. 13; 182, 1941. 30) Wever, EG., \& Lawre nce, M.: Physiological Acoustics; 115, 1954, Prienceton Univ. Press U.S.A. 31) Johansen, H.: Relation of Audiograms to the Impedance For. mula Acta Oto-laryng. Supple. $74 ; 65,1948$. 32) Onchi, Y.: A Study of the Mechanism of the Middle Ear J. Acoust. Soc. Amer. 21 ; 404, 1949. 33) Wever, E.G., \& Lawrence, M.: Transmission. Properties of the Middle Ear Ann. of Otol. 59; 5, 1950. 34) Zwislocki, J.: Some Impedance. Measurements on Normal and Pathological Ears. J. A coust. Soc. Amer. 29; 1312, 1957 . 35) Bárany, R.: Ueber neue Stimgabelversuche Mschr. Ohrenheilk. 43; 336, $1909 . \quad$ 36) Lüscher, E.: Untersuchungen über die Beeinflussung der HöIfahigkeit durch Trommelfellbelastung Acta Oto-

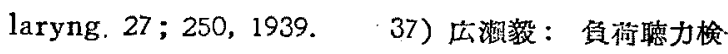

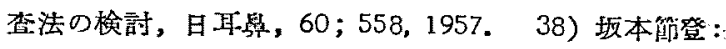

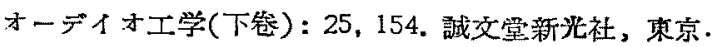
39) Fowler, E.P.. Theoretical Interpretation of the Functional Test Arch. of Otolaryngo. 7;; 606,

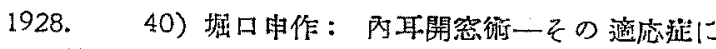
ovit, 日留, 56, 210, 1953. 41) Pohlmen, A:G. \& Kranz, F.W.: The Influence of Partial and. Complete Occulsion of the External Auditory. Canals on Air and Bone Transmitted Sound Ann. of Otol. 35; 113, 1926. 42) Kelley, N.H., \& Re. ger, S.N.: The Effect of Binaural Occulusion of the External Auditory Meati on the Sensitivity of the Normal Ear for Bone Conduction J. Ex. per. Psychol. 21; 211, $1937 . \quad$ 43) Sullivan, J.A., Gotlieb, C.C., \& Hodges, W.E.: 'Shift of Bone Conduction Threshold on Occulusion of the External Ear Canal Laryngoscope 57;690, 1947. 44) Pohlman, E.M.: Ann. of Otol. 57 ; 483, 1948. 45) Zöllnor, F.: Die bisherigen Ergebniss der 

応用 (Gellé 検楂法の新解秎)

Schallsondenuntersuchungen Arch. Ohr. u.s.w. Method Acta Oto-laryng. 39; 406, 1951. 51) 辰 Heilk. u. Z. Hals. usw. Heilk. 159; 358, 1951. 己敏交：人体聴器の豆製インピーダンスの湘定並びに

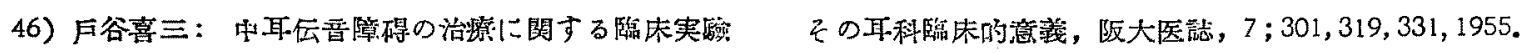
的研究，日耳算，57；891，1954. 47) Thullen, A.: $\quad$ 52) Zwislocki, J.: Some Measurement of the ImpDie Schallonde 1955, Georg Thieme Verlag. Stu- edance at the Ear Drum J. Acoust. Soc. Amer. ttgart 48) Békésy, G. von: Ueber die Mecha- 29;349, 1957.

nisch-akustischen Vergänge beim Hören Acta Oto-laryng. 27; 281, 1939. 49) Metz, O.: The Acoustic Impedance Measured on Normal and Pathological Ears Acta Oto-laryng. Suppl. 63; 1946. 50) Jepsen, O.: The Threshold of the Reflex of the Intratympanic Muscles in a Normal Material Examined by Means of the Impedance

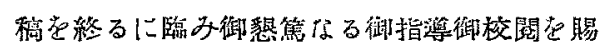

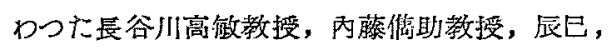
伊藤而博士に深了感謝します。

（原碻到着 $=$ 昭和 33.7.29 日一急載） 